\title{
Pancasila and multicultural values to strengthen citizens ethics in encountering global challenges
}

\author{
S. Dharma*, Hodriani, R. Nababan \& S. Hadiningrum \\ University State of Medan, Medan, Indonesia \\ R.J. Moertiono \\ Muhammadiyah University of North Sumatra, Medan, Indonesia
}

\begin{abstract}
This study examined the ethics of citizens facing various global challenges internalizing the value of Pancasila and respecting others as a multicultural nation-state, Indonesia. Applying a qualitative approach, this study collected data from experts in the field of civics, lecturers of Pancasila and Civic Education in several universities in Indonesia. The results showed that a joint commitment was needed in solving various global challenges regardless of ethnicity, race, or religion. In order to strengthen the citizen's commitment as a nation, it was necessary to internalize the values of Pancasila and the fact that Indonesia was a multicultural nation. The values that need to be internalized have three dimensions: personal dimension, interactive dimension, public dimension, and social dimension.
\end{abstract}

Keywords: Pancasila, multiculturalism, citizen ethics, global challenges

\section{INTRODUCTION}

The world is currently facing various global challenges that affect social life both at the local and national levels. Various global issues such as environment, humanity, health, economy, and politics that occur in one country will affect other countries. As with various traditional and nontraditional global issues which are currently experiencing strengthening and having an impact on world life (Winarno 2014). Currently, about one point one billion people are at high risk of being affected by violent conflicts that occur in the future. In fact, most of the violence occurs intra-state, between civilians, not inter-state, between countries (Bhargava 2019). The International Institute for Strategic Studies (IISS) states that due to the global conflict throughout 2015 the death toll has reached 167,000 (BBC 2019). Likewise, with the Covid-19 virus which initially developed in Wuhan China, now has an impact on almost all regions in the world including Indonesia. The question is what kind of ethics citizens should have to face various global challenges, what are the values contained in Pancasila that can be used as guidance in facing various challenges, both local, national and global? The multicultural values of the Indonesian people can be used as a reference to behaving and acting like citizens.

Pancasila is the foundation of the Republic of Indonesia. The values of Pancasila have existed long before the Indonesian nation founded the state. These values come from the customs, culture, and religious values of people who lived long in the archipelago region before it was called Indonesia (Kaelan 2013). Further, when Indonesia is founded, these values are inherent in everyday life as a way of life for the nation. Furthermore, the founders of the state explored and formulated these values to become the basis of the Indonesian state philosophy (Alqadri 2009). There are various

${ }^{*}$ Corresponding Author 
essential values contained in Pancasila, namely Divinity, Humanity, Unity, Population, and Justice. These values objectively serve as guidance of the Indonesian people in thinking, acting, and behaving. These values encourage social awareness in the form of moral obligations as a consequence in a pluralistic society. These moral consequences then give birth to attitudes, characters, and behaviors to exploit and increase the positive potential by reducing negative prejudices that hinder change for future progress (Cameron 2018). In facing various global challenges, values are needed as the basis of thinking and acting. These values then become the ethics of citizens to take part in facing and solving various global challenges.

To achieve the human welfare of the twenty-first century, a global ethic is needed, so that everyone can act based on their obligations as a human being regardless of nationality or identity. Everyone has a moral imperative with various skills, knowledge, and values that can be used to act in an increasingly global society (Convery \& Kerr 2007). Because there are various global problems and challenges that must be resolved collectively based on the values that are believed to guide behavior and actions. In the Indonesian context, these values come from Pancasila and Multicultural values. This paper examines the urgency of Pancasila and the multicultural values of the Indonesian nation in strengthening the ethics of citizens facing global challenges. This paper will examine what universal values can be used as guidelines in attitudes and actions to face global problems and challenges.

\title{
2 METHODS
}

This study applied interviews as the main technique to collect data. The interviews obtained data about the thoughts and views of respondents on the topic of this research. The respondents involved are experts in the field of civics and lecturers of Pancasila Education and Citizenship Education. The research was conducted at Indonesian Education University, Medan State University, and Yogyakarta State University. In addition to the interview, this study included group discussions (FGD) and documentation studies. Qualitative data analysis of Milles and Huberman (2007) was applied to stream of data reduction, data presentation, and drawing conclusions/verification.

\section{RESULTS AND DISCUSSION}

\subsection{Joint commitment in resolving various global challenges}

The citizens of the world are members of the human community that have responsibilities beyond the boundaries for their nation and state. According to Noddings (2005) and Chong (2015), global citizens who care about the economy, social justice, the earth, social diversity, culture, and peace are those who involve identity, loyalty, or commitment beyond the borders of their nation.

This opinion is in line with what was stated by respondents through interviews which explained that:

\begin{abstract}
"Every citizen has a responsibility in responding to various global challenges. To strengthen this responsibility, a number of skills are needed. Those skills are social responsibility, which is understanding inequality, global justice, empathy, and caring, and personal responsibility, and the interrelation of global problems; global competence, related to why it is important that global competencies are given to students. Global competencies such as self-awareness, intercultural communication, and global knowledge; involvement as global citizens, namely the values that will arise as a result of the involvement of students in community organizations. For example, at the international level, political aspirations, activism as a global citizen."
\end{abstract}

What the respondents said above was in line with what was stated by other respondents, "Because we are in a global era, we must always be able to think globally even though we have to act locally. For this reason, the role of global citizens must be strengthened in everyone, including students". Adding to that, another respondent said, "To become a proactive citizen, the responsibility as a 
global citizen must be cultivated to become citizens who behave fairly, fairly, peacefully, tolerant, inclusive, safe and sustainable".

From the opinions of those respondents, it can be understood that "Everyone has a responsibility to solve various global problems and challenges. Like it or not, global trends will affect the lives of citizens, so that everyone has an obligation to be involved in it". As citizens, everyone is called to understand various issues such as agriculture, human rights, ecology, and so on which ultimately unites people from various countries (Nussbaum 2002). To achieve this goal, three capacities are needed by citizens, namely ability to perform critical self-examination, ability to think as citizens of the world, and narrative imagination, namely the ability to think what it feels like in the shoes of people who are different from oneself.

In this regard, it can be understood that global problems and challenges are the responsibility of everyone regardless of ethnicity, ethnicity, religion, or even nation. Because humans are actually global citizens who must learn how to recognize the humanity of all humans (Enslin 2011). The attitude of trans-national solidarity will encourage faster resolution of various global problems and challenges. Moreover, this attitude of solidarity is formed and comes from the cultural values of each nation.

\subsection{Citizen ethics sourced from Pancasila and the multicultural values of the Indonesian nation}

For Indonesia, the presence of Pancasila is the nation's greatest gift. The values of Pancasila are the deepest dimension which is the source of ethics and morals of the Indonesian nation which then develops in the form of attitudes and behaviors or real actions in the lives of citizens (Yuliarto et al. 2020). As a source of ethics and national morals, Pancasila is used as a guide for thinking and acting in solving various global problems and challenges. This is in line with what was stated by respondents who stated that "The values of Pancasila must be used as the basis for strengthening responsibility and global awareness in citizens". This opinion is supported by other respondents who stated that "Indonesia is a very plural country bound by the Pancasila Ideology. For that, how do we now make Pancasila a guide in thinking and acting both at the local, national, and global levels?"

For example, how the fourth principle of Pancasila, namely "Social Justice for All Indonesian People", can be interpreted that social justice obliges countries to think about the welfare of humanity (Kaelan 2013). Social justice regulates the relationship between countries and the world community or vice versa which is based on efforts to uphold the basic rights of mankind (Kaelan 2013).

Apart from Pancasila, Indonesia has virtuous values that come from various customs, cultures, and religions in Indonesia. Currently, there are more than 1300 ethnic groups in Indonesia and 6 religions recognized by the state. Every ethnicity and religion have noble values that can serve as guidelines for behavior. These values are universal which govern the relationships of everyone in social life. For example, justice where every tribe, ethnicity or religion respect that value. Furthermore, compassion, namely there is no nation that does not support the value of compassion. As well as caring, respecting, etc. which are also basic values in every ethnicity, ethnicity or religion.

From this explanation, the ethics of citizens in facing various global problems and challenges are universal values that serve as guidelines in the thinking and attitude of the Indonesian nation which are described below.

Figure 1 shows the 4 dimensions of values that are the source of extracting universal multicultural values. Universal concerns the development of a shared (collective) identity and embracing the same values of all mankind (respect for human life, environmental preservation, and others). The universal values referred to are values that can be understood and accepted by all ethnic groups, races, cultures, and religions in Indonesia. These four values are at the same time the basis of humans to make conscious decisions based on human instincts and emotions (Cameron 2018).

Values that have a personal dimension are values that come from within (conscience) so that they are able to distinguish between right and wrong. Examples of characters that have a personal 


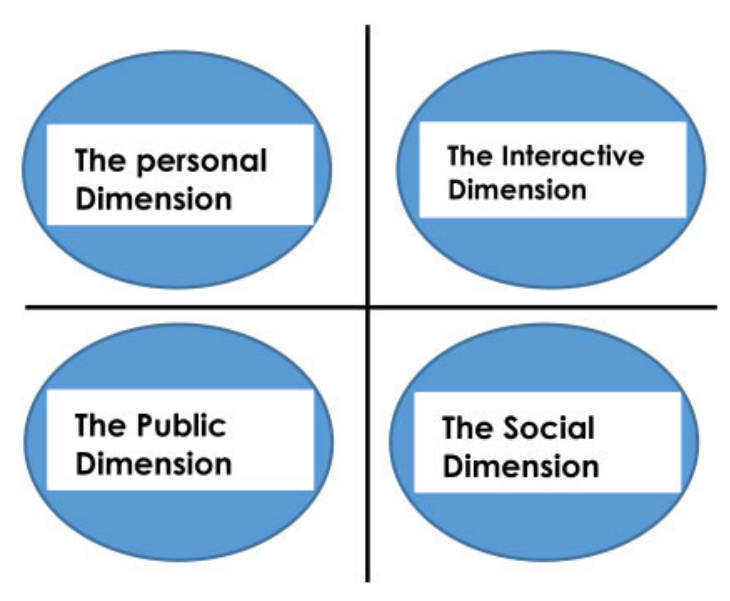

Figure 1. Four dimensions that become the source of extracting multicultural values.

dimension are religious, honest, loyal, empathetic, conscious, etc. The interactive dimension is the values that a person uses to establish relationships (interactions) with other people. Examples of these values are responsibility, discipline, desire to do your best, friendship, etc. Values with a social dimension, namely the values that are used by everyone in carrying out their life in the midst of society. Examples of this value are mutual cooperation, politeness, respect and respect for differences (tolerance), harmony, social care, etc. Finally, values have a public dimension, namely universal values that are recognized, practiced, and fought for by all people in the world. Examples of these values are equality, justice, sustainability, caring for the environment, loving peace, democracy, etc.

These values become a reference for citizens in thinking and acting when facing various global problems and challenges. For example, the world is currently facing armed conflict that has resulted in civilians becoming victims. Armed conflict is very contrary to the values that exist in Pancasila as well as the multicultural values of the Indonesian as a nation that want peace, compassion, mutual respect for differences, and so on. Likewise with the environmental crisis due to global warming. Everyone can reflect on how the teachings originating from Pancasila and the customs, culture, and religion in Indonesia teach us to love nature without destroying it. When these values are implemented, everyone will realize that how to treat others will have implications for the meaning of justice for all mankind (Enslin 2020).

\section{CONCLUSIONS}

The world is currently facing various global challenges that affect people's lives both at the local and national levels. For that, we need collective efforts of citizens to solve it. One effort that can be done is to strengthen the Pancasila and multicultural values of the Indonesian nation.

The values of Pancasila and the multiculturalism of the Indonesian people are universal values that serve as guidelines in thinking and acting by citizens in responding to various global problems and challenges. These universal values originate from the teachings of customs, culture, and religion in Indonesia. These values are then used as citizen ethics in behaving and acting. The value in question is (1) values that have a personal dimension (care and awareness, etc.); (2) value with interactive dimension (responsibility, etc.); (3) values that have a public dimension (fairness, equality, etc.); and (4) values with a social dimension (mutual cooperation, etc.).

So, a joint commitment is needed in solving various global challenges regardless of ethnicity, ethnicity, race, or religion to strengthen this commitment, it is necessary to internalize the values 
that are derived from Pancasila and the Multicultural values of the Indonesian nation which include four dimensions, namely values with a personal dimension; interactive dimension value; values that have a public dimension; as well as values with a social dimension

\section{REFERENCES}

Alqadri, S.I. 2009. Pluralisme dan multikulturalisme dalam pemeliharaan kerukunan umat beragama. In Memelihara Kerukunan Melalui Pendidikan Multikultural: 13-34. Jakarta: Kedeputian Bidang Koordinasi Pendidikan, Agama dan Aparatur Negara.

BBC. 2019. Korban akibat konflik global mencapai 167.000 jiwa. Retrieved from https://www.bbc.com/ indonesia/dunia/2016/05/160505_dunia_perang

Bhargava, V. 2006. Introduction for global issue. In B. Vinay (Ed.), Global issue for global citizens an introduction to key: 1-30. Washington: The World Bank.

Cameron, J.D. 2018. Communicating cosmopolitanism and motivating global citizenship. Political Studies, 66(3): 718-734.

Chong, E.K. 2015. Global citizenship education and Hong Kong's secondary school curriculum guidelines. Asian Education and Development Studies 4(2): 221-247

Convery, A. \& Kerr, K. 2007. Acting locally to have global impact: Citizenship Education in theory and practice in England. Citizenship, Social and Economic Education 7(3): 189-200.

Enslin, P. 2011. Education for global citizenship: The cosmopolitan and the patriotic. Citizenship, Social and Economic Education 10(2): 91-10.

Kaelan, M.S. 2013. Negara kebangsaan Pancasila: Kultural historis, filosofis, yuridis dan aktualisasinya. Yogyakarta: Paradigma.

Miles \& Huberman, A. 2007. Analisis data kualitatif: Buku sumber tentang metode-metode baru. (T. Rohendi, Trans). Jakarta: Universitas Indonesia Press.

Noddings, N. 2005. Educating citizens for global awareness. New York: Teacher College Press.

Nussbaum, M. 2002. Education for citizenship in an era of global connection. Studies in Philosophy and Education 21: 289-303.

Winarno, B. 2014. Dinamika isu-isu global kontemporer. Yogyakarta: Center of Academy Publishing Servicer (CAPS).

Yuliarto, A. et al. 2020. Bidang studi empat konsensus kebangsaan: Sub bidang studi Pancasila. Jakarta: Lembaga Ketahanan Nasional Republik Indonesia. 